\title{
Consequences of Injury Caused by Cameraria caryaefoliella (Lepidoptera: Gracillariidae) on Pecan Gas Exchange and Chlorophyll Fluorescence
}

\author{
Leonardo Lombardini ${ }^{1}$ and Astrid Volder \\ Texas A\&M University, Department of Horticultural Sciences, TAMU 2133, College Station, \\ $T X 77843-2133$
}

\begin{abstract}
Monte L. Nesbitt
Texas A\&M AgriLife Extension Horticulture, Texas A\&M University, College Station, TX 77843-2134

Donita L. Cartmill

School of Agriculture, University of Wisconsin-Platteville, Platteville, WI 53818-3099

AdDitional IndeX words. Carya illinoinensis, carbon assimilation rate, leaf injury

Abstract. After an outbreak of blotch leafminer (Cameraria caryaefoliella) on field-grown pecan (Carya illinoinensis) trees in 2010, an experiment was conducted to evaluate the consequences of the injury on carbon assimilation and photosynthetic efficiency, and, in particular, to assess if low-to-moderate injury induces a compensatory increase in photosynthesis. Gas exchange and light-adapted fluorescence were measured on non-injured portions of the leaflet lamina adjacent to the injured area as well as on portions of leaflets that included leafminer injury. Results indicate that damage of the photosynthetic apparatus did not extend beyond the injured areas by leafminers. Furthermore, although a strong relationship between the proportion of leafminer injury and area-based net $\mathrm{CO}_{2}$ assimilation rate of injured leaflet tissue was found, there was no evidence that pecan leaves were able to compensate for leafminer injury by upregulating $\mathrm{CO}_{2}$ assimilation in leaflet tissue that was unaffected.
\end{abstract}

Pecan is native to North America (Thompson and Grauke, 1991) and has been used since prehistoric and early historic times as an important source of food and timber (Hall, 2000). It has been commercially cultivated since the mid-1800s and is currently an important agricultural/horticultural crop. The United States is the world's largest producer of pecans, accounting for $\approx 58 \%$ of the market share with an estimated annual value of $\approx \$ 400$ million (U.S. Department of Agriculture, 2012). However, pecan's pest ecology presents serious challenges to the economic success of commercial pecan production in the United States.

The pecan blotch leafminer (Cameraria caryaefoliella) is one of four species of leafmining Lepidoptera that commonly infest pecan trees in the southern United States (Heyerdahl and Dutcher, 1985). Leafminers is a generic term to describe arthropods belonging to different orders whose larvae feed or "mine" between the upper and lower epidermal leaf surfaces. The mining activity creates tiny tunnels or "galleries" in the leaf causing localized necrotic and dead areas. Leafminer injury is visually evident, but healthy plants can tolerate substantial injury although there are growth (Wagner et al., 2008) and yield penalties (Percival et al., 2011; Thalmann et al., 2003). Harris and Lee (2012) indicated that the action level for leafminers in pecan is one to two larvae per leaf; however, such thresholds

Received for publication 24 Jan. 2013. Accepted for publication 15 Apr. 2013. This project was funded in part by the Texas A\&M AgriLife.

Mention of a trademark, proprietary product, or vendor does not constitute a guarantee or warranty of the product by the authors, the Texas A\&M University, the Texas A\&M AgriLife, or sponsors of the research and does not imply its approval to the exclusion of other products or vendors that also may be suitable.

${ }^{1}$ Corresponding author. E-mail: 1-lombardini@tamu.edu. may not consider physiological compensatory measures to offset injury.

The impact of leafminers and other herbivores on the photosynthetic performance of leaves is difficult to estimate because of several variables such as location of the injury (onvein vs. between veins) (Layne and Flore, 1992; Oleksyn et al., 1998), species (Oleksyn et al., 1998), intensity of the injury, induced production of allelochemicals, and proximity to injured area (Zangerl et al., 2002). One approach to investigate the effects of foliage feeders on leaf physiology is to simulate defoliation by artificial removal of portions of the leaf lamina and study the consequences on the intact portion of the leaf. Although the approach of artificially clipping parts of the leaf lamina can be useful as a preliminary study, it may not reflect feeder injury accurately, because it fails to take into account the possible role of biochemicals secreted by the herbivores (Delaney et al., 2008; Poston et al., 1976).

Plant response to herbivory injury is highly variable across and within different plant species. During heavy leafminer infestations, leaves look bleached or faded, their physiological functions and anatomical structures are disrupted, and their aesthetic value is reduced. In some cases, the feeding galleries may become points of entry for pathogenic fungi and bacteria. Increased inoculum production and disease spread have been observed for citrus canker caused by the bacterium Xanthomonas axonopodis pv. citri after infestation by the asian leafminer (Phyllocnistis citrella) (Das, 2003).

One of the most direct consequences of herbivory attack is injury of portions of the leaf lamina, which is associated with a reduction in whole-plant carbon assimilation (Raimondo et al., 2003; Schaffer et al., 1997; Welter, 1989). The actual impact on the physiological functions of the non-injured tissue may be 
species-dependent. Leafminer injury to functional integrity of the photosynthetic system of horse chestnut (Aesculus hippocastanum) did not extend beyond the mines (Raimondo et al., 2003). However, a study conducted to examine the effects of caterpillar injury in wild parsnip (Pastinaca sativa) revealed that the adverse effects of caterpillar feeding on photosynthesis extended beyond the injured areas (Zangerl et al., 2002). The indirectly affected area was six times as large as the area directly injured by the caterpillars. Moreover, the size of the indirectly affected area was positively correlated with the synthesis of furanocoumarins, defense-related compounds, suggesting that the indirect effects of herbivory on plants may be related to the cost of chemical defense through increased respiration rates (Zangerl et al., 2002).

In a few cases, a compensatory increase in photosynthetic rates has been reported as a consequence of removal of a portion of the leaf lamina. Layne and Flore (1992) found that simulated removal of less than 30\% of the leaf lamina of 'Montmorency' sour cherry (Prunus cerasus) induced higher estimated carboxylation efficiency and ribulose-1,5-bisphosphate regeneration capacity in the remaining area. Photosynthetic rate of the noninjured portion of grey alder (Alnus incana) and european alder (Alnus glutinosa) leaves grazed by the alder beetle (Agelastica alni) was increased by $10 \%$ to $50 \%$ (Oleksyn et al., 1998). Because of this compensatory increase in photosynthesis, a net reduction in photosynthesis per leaf occurred only when the proportion of leaf area grazed was greater than $40 \%$ in grey alder and greater than $23 \%$ in european alder (Oleksyn et al., 1998).

Pecan leafminers are present in the entire pecan-growing region of the United States and are usually considered a minor pest (Sutherland, 2011); however, occasional severe infestations occur (as observed in the present study). It is not known what the physiological consequences of leafminer infestation on gas exchange are and whether pecan shows any compensatory response. The objective of this study was to investigate the effects of pecan blotch leafminer on carbon assimilation and photosynthetic efficiency in pecan leaves. The hypotheses were that low-to-moderate injury induces a compensatory increase in photosynthesis and that degree of the compensation is proportional to the intensity of the injury.

\section{Material and Methods}

SiTE. The experiment was conducted on 4 Aug. 2010 in a commercial irrigated 32-year-old pecan orchard located in the Brazos River bottom near Caldwell, TX (lat. 30 $36^{\prime} \mathrm{N}$, long. $\left.96^{\circ} 30^{\prime} \mathrm{W}\right)$. The orchard was chosen because of a severe C. caryaefoliella infestation, which peaked around the date chosen for the measurements.

The soil type was a silt loam, $0 \%$ to $1 \%$ slope, belonging to the Coarsewood series, which is defined as "very deep, well-drained, moderately rapidly permeable soils that formed in calcareous, loamy alluvium" (U.S. Department of Agriculture, 2008). The orchard area chosen for the study was selected based on uniformity of tree size and vigor. All trees (cv. Wichita) were spaced at $11.6 \times 11.6 \mathrm{~m}$ and their height was $\approx 13 \mathrm{~m}$. The orchard was regularly irrigated throughout the growing season and, during July and August, it received $203 \mathrm{~m}^{3} \cdot \mathrm{ha}^{-1}$ of water delivered every $5 \mathrm{~d}$ through a buried drip irrigation system.

Gas EXChange. Net $\mathrm{CO}_{2}$ assimilation rate (A), transpiration rate $(\mathrm{E})$, and stomatal conductance $\left(g_{\mathrm{S}}\right)$ were measured on single lateral leaflets (pecan is a deciduous plant with imparipinnate leaves) using an infrared gas analysis system (LI6400XT; LI-COR, Lincoln, NE) with a fluorescence chamber attachment [2-cm ${ }^{2}$ leaf area (LI 6400-40, LI-COR)]. Measurements were performed on leaflets attached to one branch (1 to $2 \mathrm{~cm}$ stem diameter) collected $\approx 5 \mathrm{~m}$ from the ground of 10 randomly selected trees. Branches were cut using a pole pruner and cut again immediately before the stem was placed in a flask filled with reverse osmosis water. Gas exchange and lightadapted fluorescence was measured between 1000 and $1200 \mathrm{HR}$ on three fully expanded leaflets per branch (30 leaves total). Leaflets were initially selected based on a visual estimate to represent the entire range of actual injury in the data set. Measurements were taken on the non-injured portion of the leaflet lamina, adjacent to the injured area. Chamber air $\mathrm{CO}_{2}$ concentration was set at $390 \mu \mathrm{L} \cdot \mathrm{L}^{-1}$, temperature at $35^{\circ} \mathrm{C}$, and irradiance at $1200 \mu \mathrm{mol} \cdot \mathrm{m}^{-2} \cdot \mathrm{s}^{-1}$. After gas exchange measurements were performed, the same portion of the leaflet was immediately acclimated to dark using lightweight leaf clips for a minimum of $30 \mathrm{~min}$ (Greer, 1995). Measures of maximum quantum efficiency of PSII photochemistry $\left(\mathrm{F}_{\mathrm{v}} / \mathrm{F}_{\mathrm{m}}\right)$ were collected on dark-adapted leaflets and measures of PSII maximum efficiency $\left(\mathrm{F}_{\mathrm{v}}{ }^{\prime} / \mathrm{F}_{\mathrm{m}}{ }^{\prime}\right)$ were collected on light-adapted leaflets using a continuous excitation chlorophyll fluorescence analyzer (Handy PEA; Hansatech Instruments, Kings Lynn, U.K.). In addition to measurements on non-injured portions of the leaflets, an additional set of gas exchange readings was collected on 10 leaflets in which injury by the leafminer was included in the chamber to assess the effect of leafminer injury on overall leaf gas exchange rates (40 leaflets total). The area where measurements were taken was carefully indicated on the leaflets. After measurements, leaflets were placed in sealed plastic bags and stored on ice for total and injured leaflet area analysis.

LEAFLET AREA. Blotch leafminer tissue injury resulted in translucent necrotic tissue, which was distinguished from healthy tissue using color analysis. Total leaflet area and the fraction of total leaflet injury and the leaflet portion for gas exchange measurements were determined using a high-precision scanner and WinRhizo Pro software (v2009c; Regent Systems, Quebec, Canada) using the color analysis feature.

EXPERIMENTAL DESIGN AND STATISTICAL ANALYSIS. Data were analyzed using linear regression, regressing measured physiological parameters of damaged and undamaged leaf portions against either total leaf damage or damage to the measured portion.

\section{Results and Discussion}

No injury-free leaflet could be identified and the measured degree of injury ranged between 10\% (approximately five mines/leaflet $)$ and $51 \%(\approx 15 \mathrm{mines} / \mathrm{leaflet})$ of the leaflet lamina. Rates of net photosynthesis in the injured portion of the leaflet lamina declined strongly as injury in the measured area increased (Fig. 1) as did related parameters including $g_{\mathrm{S}}$ and $\mathrm{E}$ (Table 1). However, there were no changes in A of noninjured leaflet lamina as injury to the surrounding leaflet lamina increased (Fig. 2A; Table 2). The only parameter that was affected by injury to the surrounding leaflet area was $\mathrm{F}_{\mathrm{v}}{ }^{\prime} / \mathrm{F}_{\mathrm{m}}{ }^{\prime}$ (Fig. 2B), which is an indication of reduced efficiency of photosystem II. However, our data indicate that this decline in efficiency was not strong enough to affect A. Welter (1989) 


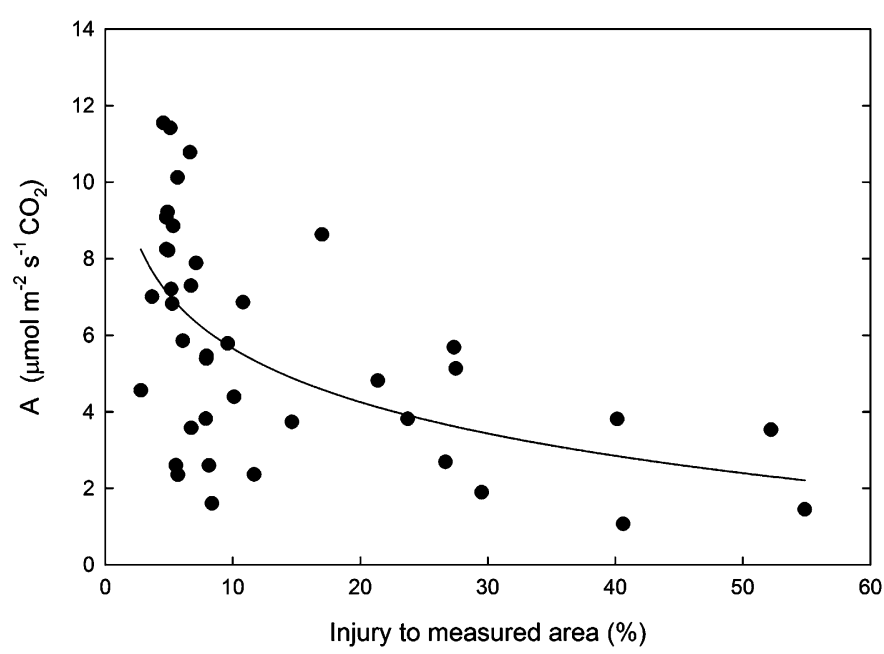

Fig. 1. Net photosynthesis (A) of injured lamina of pecan leaflets attacked by blotch leafminer as a function of measured leaf area injured; $A=10.317-$ $2.0238 \times \ln (\%$ leaf injury $), P<0.001(\mathrm{n}=40)$.

reviewed seven studies that investigated the effects of leafminers on photosynthesis. The two studies describing the consequences of injury caused by lepidopterous leafminers Phyllonorycter blancardella (Gracillariidae) and Bucculatrix pyrivorella (Bucculatricidae) reported reduction in photosynthetic rates in the undamaged portion of the leaf. Of the other five studies, three reported a decrease, one reported an increase, and one reported no change in photosynthesis after injury caused by dipterous insects (Welter, 1989). Raimondo et al. (2003) reported that there was no injury to the photosynthetic system in the non-injured portion of $A$. hippocastanum leaves attacked by the leafminer Cameraria ohridella, which resulted in the establishment of a 1:1 relationship between loss of leaf lamina and photosynthesis loss. In our study with pecan, a similar pattern was observed, because leaflet A declined as blotched area increased but the non-injured portions of the leaflets were unaffected. We did not find an increase in A of the non-injured leaflets and thus, no compensation for the decline in A of the injured areas as observed by Layne and Flore (1992) and Oleksyn et al. (1998).

The decline in $\mathrm{F}_{\mathrm{v}}{ }^{\prime} / \mathrm{F}_{\mathrm{m}}{ }^{\prime}$ with increasing injury to the surrounding leaflet lamina suggests that leafminer injury affected efficiency of PSII in non-injured leaflet portions

Table 1. Relationship between injury intensity and photosynthetic/gas exchange parameters [net $\mathrm{CO}_{2}$ assimilation rate (A), stomatal conductance $\left(g_{\mathrm{S}}\right)$, transpiration rate $(\mathrm{E})$, maximum quantum efficiency of PSII photochemistry $\left(\mathrm{F}_{\mathrm{v}} / \mathrm{F}_{\mathrm{m}}\right)$, and PSII maximum efficiency $\left.\left(\mathrm{F}_{\mathrm{v}}{ }^{\prime} / \mathrm{F}_{\mathrm{m}}{ }^{\prime}\right)\right]$ in pecan leaflets attacked by blotch leafminer. ${ }^{\mathrm{z}}$

\begin{tabular}{lccr}
\hline Parameter & Slope & $r^{2}$ & $P$ \\
\hline $\mathrm{A}$ & -0.0230 & 0.286 & $<0.001$ \\
$g_{\mathrm{s}}$ & -0.0015 & 0.160 & 0.011 \\
$\mathrm{E}$ & -0.0348 & 0.168 & 0.009 \\
$\mathrm{~F}_{\mathrm{v}} / \mathrm{F}_{\mathrm{m}}$ & - & 0.036 & 0.317 \\
$\mathrm{~F}_{\mathrm{v}}{ }^{\prime} / \mathrm{F}_{\mathrm{m}}{ }^{\prime}$ & -0.0021 & 0.154 & 0.012
\end{tabular}

${ }^{\mathrm{z}} \mathrm{A}$ and $\mathrm{F}_{\mathrm{v}} / \mathrm{F}_{\mathrm{m}}$ were ln-transformed before analysis. Slopes are not indicated when not significant.

$r^{2}=$ coefficient of determination.

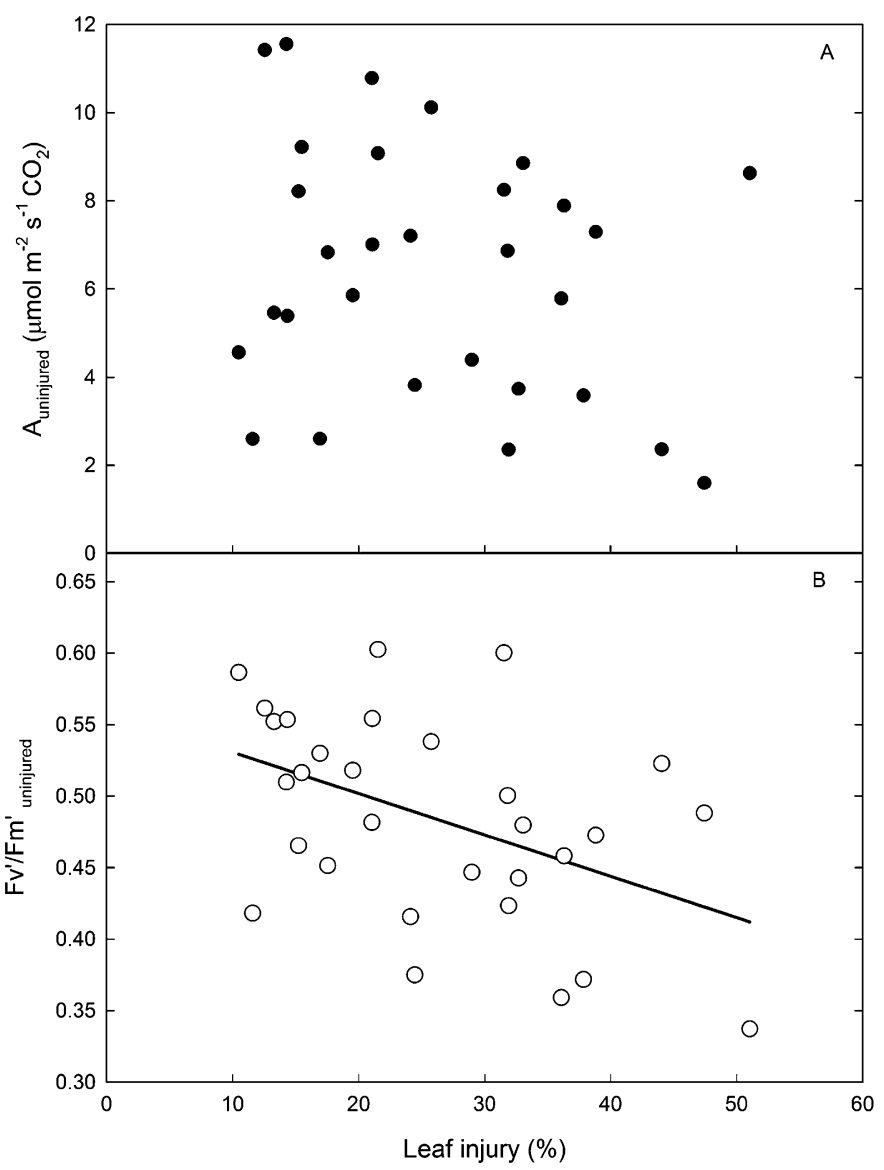

Fig. 2. Net photosynthesis rates $\left(A_{\text {uninjured }}\right)$ (A) and PSII maximum efficiency $\left(\mathrm{F}_{\mathrm{v}}{ }^{\prime} / \mathrm{F}_{\mathrm{m}}{ }^{\prime}\right.$ uninjured $)$ (B) of non-injured portions of pecan leaflets attacked by blotch leafminer as a function of total injury observed on the whole leaflet; $\mathrm{F}_{\mathrm{v}}{ }^{\prime} / \mathrm{F}_{\mathrm{m}}{ }^{\prime}=0.5595652-0.0028904 \times \%$ leaf injury, $P=0.011(\mathrm{n}=30)$.

(Tables 1 and 2). This effect was negative and its magnitude was proportional to the size of the effect in injured lamina. The mechanism for this response in the non-injured leaflet portions is, however, unclear. Perhaps leafminer injury leads to increased radical oxygen species (ROS) production. In cells with high ROS production, this "hypersensitive response" leads to rapid cell death (Levine et al., 1994). Because ROS are damaging to membrane integrity, a small upregulation of ROS production may also affect membrane functioning of

Table 2. Relationship between injury intensity and photosynthetic/gas exchange parameters [net $\mathrm{CO}_{2}$ assimilation rate (A), stomatal conductance $\left(g_{\mathrm{S}}\right)$, transpiration rate $(\mathrm{E})$, maximum quantum efficiency of PSII photochemistry $\left(\mathrm{F}_{\mathrm{v}} / \mathrm{F}_{\mathrm{m}}\right)$, and PSII maximum efficiency $\left.\left(\mathrm{F}_{\mathrm{v}}{ }^{\prime} / \mathrm{F}_{\mathrm{m}}{ }^{\prime}\right)\right]$ of non-injured lamina of pecan leaflets attacked by blotch leafminer. ${ }^{\mathrm{z}}$

\begin{tabular}{lccc}
\hline Parameter & Slope & $r^{2}$ & $P$ \\
\hline $\mathrm{A}$ & - & 0.056 & 0.210 \\
$g_{\mathrm{s}}$ & - & 0.056 & 0.209 \\
$\mathrm{E}$ & - & 0.045 & 0.259 \\
$\mathrm{~F}_{\mathrm{v}} / \mathrm{F}_{\mathrm{m}}$ & - & 0.061 & 0.188 \\
$\mathrm{~F}_{\mathrm{v}}{ }^{\prime} / \mathrm{F}_{\mathrm{m}}{ }^{\prime}$ & -0.0029 & 0.209 & 0.011
\end{tabular}

${ }^{\mathrm{z}} \mathrm{A}$ and $\mathrm{F}_{\mathrm{v}} / \mathrm{F}_{\mathrm{m}}$ were $\ln$-transformed before analysis. Slopes are not indicated when not significant.

$r^{2}=$ coefficient of determination. 
the non-injured cells leading to a reduced efficiency of PSII in these cells. When the reduction in PSII efficiency is small, but measurable, enough ATP and NADPH may still be produced to keep the Calvin cycle running at the same rate, thus not affecting $\mathrm{CO}_{2}$ assimilation, because only a small portion of the ATP and NADPH generated in the light reaction is actually used for the production of carbohydrates.

Leafminer injury in horse chestnut was found to reduce electron transport as well as carbohydrate storage, nut size, and the next year's yield (Percival et al., 2011). Similar to our findings, A on a whole leaf basis of horse chestnut was proportionally negatively correlated to the area affected by leafminer injury (Raimondo et al., 2003) while reducing leafminer pressure increased growth of quaking aspen (Wagner et al., 2008). Furthermore, although we found a strong relationship between the proportion of leafminer injury and A of injured leaflet tissue, we did not find any evidence that pecan trees are able to compensate for leafminer injury by upregulating $\mathrm{CO}_{2}$ assimilation in the leaflet tissue that was unaffected. These findings support adopting protective measures to limit injury caused by foliage-damaging arthropods in pecan by establishing and applying economic injury thresholds for each pest problem.

\section{Literature Cited}

Das, A.K. 2003. Citrus canker-A review. J. Appl. Hort. 5:52-60.

Delaney, K.J., F.J. Haile, R.K. Peterson, and L.G. Higley. 2008. Impairment of leaf photosynthesis after insect herbivory or mechanical injury on common milkweed, Asclepias syriaca. Environ. Entomol. 37:1332-1343.

Greer, D.H. 1995. Effect of canopy position on the susceptibility of kiwifruit (Actinidia deliciosa) leaves on vines in an orchard environment to photoinhibition throughout the growing season. Austral. J. Plant Physiol. 22:299-309.

Hall, G.D. 2000. Pecan food potential in prehistoric North America. Econ. Bot. 54:103-112.

Harris, M. and N. Lee. 2012. Pest profiles. 3 Apr. 2013.<http://pecan. ipmpipe.org/toolbox/pest_profiles/doc_pdf/pest_profiles_sm.pdf $>$.

Heyerdahl, R. and J.D. Dutcher. 1985. Management of the pecan serpentine leafminer (Lepidoptera: Nepticulidae). J. Econ. Entomol. 78:1121-1124.

Layne, D.R. and J.A. Flore. 1992. Photosynthetic compensation to partial leaf area reduction in sour cherry. J. Amer. Soc. Hort. Sci. 117:279-286.
Levine, A., R. Tenhaken, R. Dixon, and C. Lamb. 1994. $\mathrm{H}_{2} \mathrm{O}_{2}$ from the oxidative burst orchestrates the plant hypersensitive disease resistance response. Cell 79:583-593.

Oleksyn, J., P. Karolewski, M.J. Giertych, R. Zytkowiak, P.B. Reich, and M.G. Tjoelker. 1998. Primary and secondary host plants differ in leaf-level photosynthetic response to herbivory: Evidence from Alnus and Betula grazed by the alder beetle, Agelastica alni. New Phytol. 140:239-249.

Percival, G.C., I. Barrow, K. Noviss, I. Keary, and P. Pennington. 2011. The impact of horse chestnut leaf miner (Cameraria ohridella Deschka and Dimic; HCLM) on vitality, growth and reproduction of Aesculus hippocastanum L. Urban For. Urban Green. 10:11-17.

Poston, F.L., L.P. Pedigo, R.B. Pearce, and R.B. Hammond. 1976. Effects of artificial and insect defoliation on soybean net photosynthesis. J. Econ. Entomol. 69:109-112.

Raimondo, F., L.A. Ghirardelli, A. Nardini, and S. Salleo. 2003. Impact of the leaf miner Cameraria ohridella on photosynthesis, water relations and hydraulics of Aesculus hippocastanum leaves. Trees (Berl.) 17:376-382.

Schaffer, B., J.E. Peña, A.M. Colls, and A. Hunsberger. 1997. Citrus leafminer (Lepidoptera: Gracillariidae) in lime: Assessment of leaf damage and effects on photosynthesis. Crop Prot. 16:337-343.

Sutherland, C. 2011. Potential pecan pests to ponder-Leafminers and hickory shuckworm in New Mexico, 2010. Proc. $45^{\text {th }}$ Annu. Western Pecan Growers Assn., Las Cruces, NM. p. 8-10.

Thalmann, C., J. Freise, W. Heitland, and S. Bacher. 2003. Effects of defoliation by horse chestnut leafminer (Cameraria ohridella) on reproduction in Aesculus hippocastanum. Trees (Berl.) 17:383-388.

Thompson, T.E. and L.J. Grauke. 1991. Pecans and other hickories (Carya). Acta Hort. 290:839-904.

U.S. Department of Agriculture. 2008. Official soil series descriptions. 22 Mar. 2013. <http://soils.usda.gov/technical/classification/osd/ index.html $>$.

U.S. Department of Agriculture. 2012. Noncitrus fruits and nuts. 15 Apr. 2013. <http://usda.mannlib.cornell.edu/MannUsda/viewDocumentInfo. do?documentID $=1113>$.

Wagner, D., L. DeFoliart, P. Doak, and J. Schneiderheinze. 2008. Impact of epidermal leaf mining by the aspen leaf miner (Phyllocnistis populiella) on the growth, physiology, and leaf longevity of quaking aspen. Oecologia 157:259-267.

Welter, S.C. 1989. Arthropod impact on plant gas exchange, p. 135150. In: Bernays, E.A. (ed.). Insect-plant interactions. CRC Press, Boca Raton, FL.

Zangerl, A.R., J.G. Hamilton, T.J. Miller, A.R. Crofts, K. Oxborough, M.R. Berenbaum, and E.H. de Lucia. 2002. Impact of folivory on photosynthesis is greater than the sum of its holes. Proc. Natl. Acad. Sci. USA 99:1088-1091. 